Journal of Humanities, Social and Management Sciences (JHSMS)

eISSN: 2788-4791 (online)

https://doi.org/10.47264/idea.jhsms/2.2.13

Vol. 2, No. 2 (July-December 2021), 181-188

https://www.ideapublishers.org/index.php/jhsms

Review Article

\title{
Functional democracy: An analysis of the key elements of a democratic system
}

\author{
Arif Khan | Bakhtiar Khan | Muhammad Alam* \\ Department of Political Science, University of Buner, Sowari, Pakistan. \\ *Corresponding Author Email: malamawkum@gmail.com
}

Received: September 1, 2021

Published: November 28, 2021

\begin{abstract}
This article debates democracy and the key elements of a democratic system. For this purpose, some of the internationally reputed authors and experts have been quoted. There is no universally accepted definition of democracy but most of the intellectuals and scholars are agreed that in democracy the supreme authority is vested in the hands of the people who exercise it through their elected representatives. The paper adopted qualitative, historical, and analytical method. The scholar has undergone an extensive study of available literature such as books, journals articles, newspapers and internet sources to make this study more commendable and get it become visible for the future scholars. The paper is based on qualitative study as it discusses facts for finding the truth. Democracy cannot flourish without certain necessary conditions. The focus of the paper is on the fundamental's elements of democracy each of which is a basic condition for the success of democratic type of government everywhere.
\end{abstract}

Keywords: functional democracy, majority rule, minority rights, free elections, participative governance, independent media, accountability.

\section{How to Cite:}

Khan, A., Khan, B. \& Alam, M. (2021). Functional democracy: An analysis of the key elements of a democratic system. Journal of Humanities, Social and Management Sciences (JHSMS), 2(2), 181-188. https://doi.org/10.47264/idea.jhsms/2.2.13

\section{Publisher's Note:}

IDEA PUBLISHERS (IDEA Publications Group) stands neutral regarding jurisdictional claims in the published maps and institutional affiliations.

\section{Copyright:}

(C) 2021 The Author(s), published by IDEA PUBLISHERS (IDEA Publications Group).

\section{Licensing:}

This is an Open Access article published under the Creative Commons Attribution-NonCommercial 4.0 International License (http://creativecommons.org/licenses/by-nc/4.0/) 
Functional democracy: An analysis of the key elements of a democratic system

\section{Introduction}

According to Rustow democracy is a competitive and challenging process and this competition gives an edge to those who can rationalize their commitment to it and yet better edge to those who genuinely believe in it (Rustow, 1970). A democratic system is one where people choose their representatives by voting in free, fair and impartial elections. In democracy, people are afforded with a choice among different parties and their candidates who desire access to power. In a democratic system, government is based on the will of the people, and it can hope to stay as long as it enjoys the support of the masses. If the elected representatives fail to serve the public interests, the latter have the right to criticize and replace them. The elected representatives are bound to fulfil the needs and aspirations of the citizens. In the western concept of democracy, sovereignty belongs to the masses which are to be exercised through their elected representatives. Hence according to Schmitter and Karl (1991), "modern democracy is "a system of governance in which rulers are held accountable for their actions in the public realm acting indirectly through the competition and cooperation of the elected representatives (Schmitter \& Karl)".

According to Dahl (1971), "it is the responsiveness of government to the preferences of its citizens (who are, in theory, "political equals" of the rulers), that is the key characteristic of democracy (Dahl, 1971)". Such responsiveness necessitates that general public have the right to formulate their preferences, articulate them and have them considered by those at the helm of affairs. According to Churchill, "no one pretends that democracy is perfect or all-wise. Indeed, it has been said that democracy is the worst form of government except all other forms that have been tried from time to time". In the above famous quote, the former British Prime Minister Sir Winston Churchill focuses on the weak side of democracy. Of course, there is no perfect form of government in the world anywhere. But all other forms of government produce less desired results than democracy. It is the democratic system that can regulate public affairs in a better way. In simple words, a democratic system is one in which everyone is treated equally and has equal rights. When people have a voice in the government, they have more trust in it (Huntington, 1991).

Democracy is a suitable form of government particularly for a multi-ethnic society like Pakistan. The legitimacy of democracy is accepted throughout the world. Most countries of the world are moving towards the adoption of this system. Some are more developed, some are in the process of making but if internal conditions are not favourable, snowballing alone is unlikely to promote democracy in a particular country. For example, the democratization of India, UK and Turkey does not mean that there will be democracy in Pakistan unless the conditions that promote democracy are met in Pakistan. The ongoing process of democratization worldwide will certainly create an environment for those regions that are lagging behind to come up to a required level of acceptability (Huntington, 1991). In a nondemocratic state, a single party holds power that violates the human rights by misusing authority that results in a negative reaction leading to disturbance and anarchy in the country. Strikes, violence, and disorders of all sorts become routine affairs in such a polity.

A resolution (A/RES/59/201) adopted the UN General Assembly in 2004, provided for certain 'essential elements of a democracy'. A state that guarantees the observance of all or many of these elements/principles deserves to be called democratic. According to Prothro and Grigg, some basic principles for successful democracy demand that public officials should be chosen 
by majority vote, citizens should have equal opportunity and chance to affect the government, the minority should have the right to criticize majority decisions provided that are inconsistent with the state laws, the opposition political parties should be free to mobilize public opinion in support of their programs, respect for majority rule and protection of minority rights (freedom to dissent) (Prothro \& Grigg, 1960).

Beetham (2004) is of the opinion that democracy is known by different feature and by a variety of institutions as well as some practices without which the fruits of democracy cannot be realized. He states that democracy starts with human rights which is the dignity of every individual person. Further, the author holds that the core principles of democracy lay in the process through which people have right to understand as well as having controlling influence over those who are ultimate decision makers. He further emphasizes that people must be treated equally in the context of such decisions imposed by decision makers.

Pelizzo and Stapenhurst (2013) argue that parliament by performing their assigned function can play a great role for the smooth development of democracy as it will keep governments accountable to the people for their actions and decisions and thus there would be real check on the abuse of power. They have further argued that parliaments must not be restricted to the tools only but must have also the political will to oversee the government.

Becker and Raveloson (2008) analyse the function of a democratic state. They are of the view that in a real democratic state all the people are equal according to the law of the state. State can only take action according to vested power as enshrined by law and constitution. They further state that in a democratic system, the states are always accountable for their action. In such system people are free to take part in good and healthy political life.

\section{Key elements of democracy}

Some of the key elements of democracy which relate to this study are:

\subsection{Respect for majority rule and minority rights}

Majority rule is a way for any government to stay organized. Majority rule allows people to vote for or against an issue. Minorities should not be deprived of their rights. They should be treated in a fair way. Minorities will feel comfortable when they are treated fairly with no discrimination. They hold strong onto their basic rights and represent them. Though the government is of majority, the minority avails the same rights and benefits as availed by the majority. The minority rights can be well protected if they are given opportunities of participation on equal footings.

\subsection{Free, fair, and impartial elections}

The institution of representative government is inevitable for a successful democracy. Representative government should be constituted in a democratic manner i.e., to choose political leaders through periodic elections free of malpractices. In fact, it is election through people elect their representatives who then get into power legitimately. According to Katz, "Elections" "are the defining institutions of modern democracy (Katz, 1997)". All citizens use their right to vote in electing representatives of their choice who then take decisions for the 
Functional democracy: An analysis of the key elements of a democratic system

betterment of their voters. Periodic elections are the sign of a healthy political system where the chosen representatives run the system and take initiatives for the general welfare of citizens (Pelizzo, 2006). Election is a formal and organized process enabling a person to have access to a public office. It empowers the citizens to exercise their right of choosing those who would hold authority. Democracy manifests itself through the electoral process; continuous process of free and fair elections and peaceful and orderly transfer of power (Hussain, 2011).

One of the basic criteria for democracy is ensuring an equitable and open competition/choice to the electorates allowing them to choose from among different political parties without interference. Democracy gains strength when citizens are free to raise voice for their rights, when there is equality, media is free and when equitable conditions for electoral competition are ensured. In a country where a party or personality dominates the system, the playing field will be tilted in favour of the incumbent government (Huntington, 1991). Free and fair elections lead towards a sustainable democracy. It is also a mechanism of political education. The stability and growth of political institutions of a country is linked with free and fair elections. So, for a country to be democratic there would be an open competition and electorates should be given a free hand to elect candidates of their own choice (Baber, n.d.).

For political scientists, democracy is a system where the power rests with the people and where all citizens are equally entitled to influence the politics of the state. To Dahl, however, this basic democratic principle is violated:

- If citizens are not permitted to devise their political preferences

- If citizens are not permitted to express - through individual or collective action, their political preferences to their fellow citizens and to the government and

- If the government does not respect the citizens' preferences (Dahl, 1971).

The above conditions will stand fulfilled if certain rights are guaranteed under the constitution. The Constitution must protect citizens' right to associations, citizen's right to freedom of expression, right to vote, right of all eligible citizens to compete for public offices, the right to information, free and fair elections and institutional arrangements for ensuring that government's policies and actions are meant for public welfare (Dahl, 1971).

The above-mentioned rights and freedoms cover not only pre-election phase but the post also. It is to keep the government accountable for all of its actions (Schmitter \& Karl, 1991). For the stability and consolidation of a democratic system, both free and fair elections and government accountability is necessary. Accountability is inherently connected with electoral competition, and it creates a competitive environment for the representatives (Pelizzo, 2006). Sartori, for example, argued that "representation intrinsically consists of two ingredients: responsiveness and independent responsibility (Sartori, 1987)". Sartori further states that "free and fair election is by itself an instrument which ensures accountability of government".

The citizens do have the right to vote for the political parties and politicians in power, but they also have the power to vote them out. The parties have to remain sensitive to voter's demands and work for the interests of the citizens because their future depends on public support. If they 
do not remain responsive and fail in fulfilling the demands of their voters, the latter will not support them in future. Thus, the electorate may vote them out by supporting their rivals. The opposition political parties, too, have to be sensitive to voters' demands. It is because of this behaviour of opposition that justifies their claim to be a good alternate to the incumbent government whenever the incumbent fails to do its duty. But elections can seek accountability of government only if they are free and fair (Pelizzo, 2006).

\subsection{Rule of law}

Democracy stands for the rule of law. A democratic set up facilitates fair and equal application of law and procedures without any discrimination based on caste, creed or religion. Everyone is treated equally. The rule of law guarantees protection of the rights of all by putting limits on the power of government. It maintains order and protects the country from anarchy and all sorts of disturbances. No one is arrested and punished arbitrarily. All are equally treated, so as to enjoy their rights and freedom. Law is for all either head of the state or a common man. Courts are free bodies, and they implement the laws in their letter and spirit. Similarly, in a democratic set up, if someone is accused of some crime, they have the right to a fair, speedy and open trial because of the fact that they are entitled to the equal protection of law. They are innocent unless proven guilty by the court during the trail. The accused has full right to know about the charges against him, to remain silent and to be defensive. The same charges are not to be applied against him twice. Torture and torment is not allowed even though seizing his property.

\subsection{Separation of powers and independence of judiciary}

In any political system if political power is to be restricted and accountable, the independence of judiciary from executive control must be ensured. In a democracy, the exercise of political power by the elected representatives of the people must respect the law, the constitution and the will of the people. This requires that power be separated with clearly defined span of control so that the cabinet ministers could not interfere and hinder court cases. In a democratic system, it is the responsibility of the executive to put into practice programs and policies, administers budget and deal with state affairs. The executive may have the right to propose laws, however, only the elected members in the parliament who represent the people have the power of enactment. Only the courts have the power to decide the guiltiness or innocence of persons charged with a crime and only the higher courts can determine whether a law or a government action/policy is in line with the constitution.

\subsection{Independent media}

Media freedom is inevitable in a democratic set up. It not only helps in creating plural and open societies, accountable and transparent system of government but also protects human rights and fundamental freedoms. It is the free and independent media that guarantees freedom of expression and freedom of information which are the two essentials facilitating active participation of citizens in governmental business (Meyer-Resende, 2011). The press plays an important role in public awareness about government policy and other matters of importance and thus promotes a democratic culture. Those responsible are brought to the limelight and also ensure means for mutual interaction (Beetham \& Boyle, 2009). To perform these functions, the press must not only be independent, but it must also have both material and human resources to deal with all the important problems of a society (Bassiouni, 1998). 
Functional democracy: An analysis of the key elements of a democratic system

\subsection{Conflict and consensus}

Conflict and consensus occupy a central position in democracy which manifests in numerous forms. Conflicts do arise in any democratic set up but are managed amicably. All have to search for compromises, give and take, consensus or other agreements that would be acceptable to all. It should, then, discover means to alleviate disagreement and cleavage with consensus (Diamond \& Plattner, 1999). Consensus is more than the sum total of ideas of the persons in a group. ${ }^{1}$ Consensus strives to consider each disagreement and come to a decision earlier than a judgment is made. More significantly, this course encourages a setting where one and all are valued, and all contributions are appreciated. For any democratic set up to sustain, all persons and groups should be prepared to stomach each other's differences. They should admit that the competitor has a convincing right and a genuine opinion.

\subsection{Accountability of government}

In democracy political parties take part in elections, make efforts to win the elections for capturing political offices and managing governmental affairs (Doherty, 2001). In a democracy, elections are held, and the contending candidates represent their parties, and the people are free to vote to power candidates of their own choice. The political party that wins the majority of seats, forms government and exercises control over the administration (Randall \& Svåsand, 2002). Occasionally, if no party gets the required majority to form government, two or more parties join hands for a coalition government. In a democracy, political parties build a balance between demands and support such as interest expression and aggregation. It is the political parties that connect a government to the people (McKay, 2001). The party or parties which form government and acquire control of administration are responsible for every action of the government. The government can only be popular and effective when it seeks public good, protects their rights, their lives and their possessions.

Accountability is a virtue without which free, popular and powerful/strong government cannot endure long. Political parties must be provided with the means of accountability that they could make a stable and functional government. The Social Contract Theory stresses upon the need for accountability. People must have the right to replace the government if it fails in fulfilling its responsibilities (McKay, 2001). This provides a means for public accountability of government for its deeds. The masses keep in mind the previous record while electing their representatives. This fear keeps the government vigilant and responsive to public demands. If the government is accountable, the elected representative would not violate the citizens' rights and would not abuse power. An unaccountable government is always corrupt and irresponsible. It cannot function well because it is not afraid of doing wrongs. So, in short, accountability is an essential and central pillar of a successful system. It maintains a liaison between the rulers and the ruled (Akhtar, 2013).

\subsection{Participatory and deliberative democracy}

Common people have aspirations and demand for decentralization of authority and devolution of power to the locals. It is because of the lack of transparency, accountability and responsiveness of the bureaucracy that represents the centralized administration at the local level. In fact, democracy at the gross root level enriches the practice of democracy. Not only governance system will be more transparent, if power devolved to the local representatives but 
it will also be more accountable answerable to the voter. Similarly, by transferring powers to local levels will ensure increased citizen participation in public matters that affect their daily life. As the local representatives have in-depth knowledge and information about local issues and problems so it will be easier for the government to be responsive to urgent needs and redress people grievances.

\section{Conclusion}

The very fundamental value of democracy is that it will guarantee not only political freedom but should also make sure that all citizens without any discrimination are enjoying social and political participation. However, to for securing democracy to function its requirements have to be fulfilled. Ensuring majority rule and minority rights are one such demand. Majority rule allows a group to rule, and no doubt ensure a government to stay organized, but minority rights are equally important. They must be ensured their rights and privileges. Democracy is a government of the ruling parties as much as it is of the minority's parties and without taking care of minority a democracy cannot be a success. Similarly, credible election is another requirement for which there must be a proper legal framework. Through strict surveillance and appropriate feedback machinery for the voters it should be ensured that the system is effective. In the same manner to make the governance process deliberative and participative is of prime importance. To fulfil this demand of democracy decentralization of authority must be ensure to a maximum level and all centralizing tendencies should be nipped in the bud. The task of building democracy for the people cannot be secured without satisfying these demands.

\section{References}

Akhter, N. (2013). Role of political parties in the democratic system of Pakistan. Master Thesis, School of Global Studies, University of Gothenburg. https://gupea.ub.gu.se/bitstream/2077/33025/1/gupea_2077_33025_1.pdf

Baber, F (n.d.). Democracy and Elections: How elections are rigged in Pakistan. Peoples Institute of Democracy.

Bassiouni, M. C. (1998). Democracy: Its principles and achievement (Vol. 1021). InterParliamentary Union.

Becker, P., \& Raveloson, J. A. A. (2008). What is democracy? FES Publication.

Beetham, D., \& Boyle, C. K. (2009). Introducing democracy: 80 questions and answers. UNESCO.

https://www.gcedclearinghouse.org/sites/default/files/resources/181392e.pdf

Beetham, D. (2004). The quality of democracy: Freedom as the foundation. Journal of Democracy, 15(4), 61-75. https://www.journalofdemocracy.org/articles/the-qualityof-democracy-freedom-as-the-foundation/

Doherty, I. (2001). Democracy out of balance: Civil Society Can't Replace Political Parties. Policy Review, 106(25), 25-35. https://www.ndi.org/sites/default/files/1099_polpart_balance.pdf

Rustow, D. A. (1970). Transitions to democracy: Toward a dynamic model. Comparative Politics, 2(3), 337-363. https://doi.org/10.2307/421307

Diamond, L. J., \& Plattner, M. F. (Eds.). (1999). Democratization in Africa. JHU Press. 
Functional democracy: An analysis of the key elements of a democratic system

McKay, D. (2001). Designing Europe: Comparative lessons from the federal experience. OUP Catalogue. https://ideas.repec.org/b/oxp/obooks/9780199244355.html

Katz, R. S. (1997). Democracy and elections. Oxford University.

Huntington, S. P. (1991). Democracy's third wave. Journal of democracy, 2(2), 12-34. https://www.ned.org/docs/Samuel-P-Huntington-Democracy-Third-Wave.pdf

Hussain, (2011, June 25). Democracy vs Democracy. The Express Tribune. https://tribune.com.pk/story/195488/'democracy'-vs-democracy

Meyer-Resende, M. (2011). International consensus: Essential elements of democracy. Berlin/Germany: Democracy Reporting International [DRI], 1-16. http://www.concernedhistorians.org/content_files/file/to/333.pdf

Sartori, G. (1987). The theory of democracy revisited (Vol. 2). Chatham House.

Schmitter, P. C., \& Karl, T. L. (1991). What democracy is... and is not. Journal of Democracy, 2(3), 75-88. https://doi.org/10.1353/jod.1991.0033

Pelizzo, R., \& Stapenhurst, F. (2013). Parliamentary oversight tools: A comparative analysis. Routledge.

Pelizzo, R. (2006). Free and Fair Elections. Singapore Management University.

Prothro, J. W., \& Grigg, C. M. (1960). Fundamental principles of democracy: Bases of agreement and disagreement. The Journal of Politics, 22(2), 276-294. https://www.journals.uchicago.edu/doi/abs/10.2307/2127359

Dahl, R. (1971). Polyarchy: Participation and opposition. New Haven.

Randall, V., \& Svåsand, L. (2002). Introduction: The contribution of parties to democracy and democratic consolidation. Democratization, $9(3)$ $1-10$. https://www.tandfonline.com/doi/pdf/10.1080/714000270

\section{Notes:}

${ }^{1}$ Through deliberations, more ideas come to the front producing fresh ideas and as a result the most excellent decision comes out. This lively activity is called the innovative interaction of ideas. It is creativity that plays a key role in finding out what is best for the public and when more populaces are drawn in this accommodating endeavor as a result more ideas and possibilities are generated. In this respect, the relentless, indiscriminate and rigid use of parliamentary majority is essentially offensive and not consensual. The purpose has repeatedly been capturing the vote, in spite of another option that might be in the interest of the entire group; it resorts to the power of domination as an alternative of persuasion. When the will of the majority supersedes the concerns of minority, it is intrinsically conflictual? 